Cakrawala Dini: Jurnal Pendidikan Anak Usia Dini | p-ISSN 2087-I317 | e-ISSN 2621-8321

Vol. 马. No.2 November 2018 | Hal 98-10马

\title{
MENINGKATKAN PERKEMBANGAN BERBICARA ANAK MELALUI BERCERITA MENGGUNAKAN FLANNEL BOARDS
}

\author{
Eka Setiawati ${ }^{1}$, Auliyah Ulfah ${ }^{2}$ \\ STKIP Setia Budhi Rangkasbitung
}

\begin{abstract}
The research purpose are to know the progress of children's speech and know the implementation of learning with storytelling method using flannel board media, and find out whether the learning using flannel board media can improve the development of speaking 4-5 years old children in Asy-Syifa kindergarten. The method of the research is classroom action research. The model of action in use is according to the Kemmis and Mc Taggart model in which each cycle consists of four steps and three meetings: planning, execution, observation, and reflection, consisting of the first day, the second day and the third day. Data collection techniques used were observation sheets, field notes and documentation. The results showed of learning by using flannel board media with storytelling can improve the development of talking children aged 4-5 years. Pre-cycle action received 10 (36\%), showed the development of speech of underdeveloped children, after being given action in cycle I get 14 (49\%), cycle II get 23 (72\%) and in cycle III get $26(87 \%)$, result in the third cycle is considered to have succeeded, exceeding the critegmailrion assessment criteria that is $75 \%$.
\end{abstract}

Keyword: Child Speaking Development, Flannel Board Media, Storytelling Method.

\begin{abstract}
Abstrak: Tujuan penelitian ini adalah untuk mengetahui perkembangan kemampuan berbicara anak dan mengetahui penerapan pembelajaran dengan metode bercerita menggunakan media papan flanel, dan mengetahui apakah pembelajaran menggunakan media papan flanel dapat meningkatkan perkembangan berbicara anak usia 4-5 tahun di TK Asy-Syifa. Metode penelitian ini adalah penelitian tindakan kelas. Model tindakan yang digunakan adalah sesuai dengan model Kemmis dan Mc Taggart di mana setiap siklus terdiri dari empat langkah dan tiga pertemuan: perencanaan, pelaksanaan, observasi, dan refleksi, yang terdiri dari hari pertama, hari kedua dan hari ketiga. Teknik pengumpulan data yang digunakan adalah lembar observasi, catatan lapangan dan dokumentasi. Hasil penelitian menunjukkan pembelajaran dengan menggunakan media papan flanel dengan storytelling dapat meningkatkan perkembangan berbicara anak usia 4-5 tahun. Tindakan pra-siklus menerima 10 (36\%), menunjukkan perkembangan bicara anak-anak yang kurang berkembang, setelah diberikan tindakan dalam siklus saya mendapatkan 14 (49\%), siklus II mendapatkan 23 (72\%) dan pada siklus III mendapatkan 26 (87) \%), hasil pada siklus ketiga dianggap telah berhasil, melebihi kriteria penilaian critegmailrion yaitu $75 \%$.
\end{abstract}

Kata Kunci: Perkembangan Berbicara Anak, Media Papan Flanel, Metode Mendongeng.

\section{PENDAHULUAN}

Anak usia dini memiliki beberapa aspek perkembangan yang sangat penting untuk perkembangan anak, seperti aspek perkembangan kognitif, motorik, bahasa, sosial emosional, moral dan agama. Aspek-aspek tersebut membantu anak

ISTKIP Setia Budhi Rangkasbitung, Email: echasetia14国gmail.com

${ }^{2}$ TKN Pembina Cibadak, Email: auliyaulfah25国gmail.com dalam lingkungan sosial, perkembangan bahasa, penanaman moral dalam diri anak dan sebagainya, aspek perkembangan yang dimiliki anak berlangsung secara bertahap dalam waktu tertentu. Sebab itu tutor harus memberikan sarana berupa metode dan media yang di gunakan dalam 
pembelajaran yang akan membantu aspek-aspek perkembangan anak dengan baik.

Pada semua aspek perkembangan anak, terdapat salah satu aspek yang perlu diperhatikan yaitu, aspek perkembangan bahasa, untuk belajar bahasa anak memerlukan kesempatan untuk berbicara dan didengarkan dimana dalam aspek perkembangan bahasa ini memiliki empat keterampilan seperti menyimak, membaca, menulis dan berbicara (Yuliani, 2013, hlm. 185). Perkembangan berbicara merupakan suatu alat untuk mengekspresikan, menyatakan, menyampaikan, mengkomunikasikan pikiran, ide maupun perasaan (Dhieni:2011:34), oleh sebab itu aspek perkembangan bahasa dalam perkambangan bicara sangat penting di perlukan oleh anak dalam kehidupan sehari-hari. Aspek perkembangan bahasa dalam perkembangan berbicara sangat perlu di perhatikan, karna anak mampu menyatakan atau menyampaikan keinginannya dengan berbicara. Untuk dapat memperhatikan perkembangan bicara anak, maka mengetahui bahasa yang di miliki anak dapat dilakukan dengan adanya bimbingan secara intensif yang dilakukan oleh orang tua dan tutor di sekolah, menggunakan media atau metode-metode. Salah satunya dengan menggunakan metode bercerita dengan menggunakan media papan flannel, sehingga mudah dan menyenangkan untuk anak belajar dalam perkembangan berbicara.

\section{TINJUAN PUSTAKA}

\section{a. Pengertian berbicara \\ perkembangan}

Di ungkapkan oleh Seefeldt dan Wasik yang Mengatakan bahwa dalam berbicara anak harus belajar cara berbicara bergantung pada situasi, dan harus berbicara dengan cara-cara yang bisa dimengerti dan didengar orang lain (Seefeldt dan Wasik, 2008: 354). Pendapat yang sama di ungkapkan oleh Vreede Varekamp yang mengatakan bahwa manusia mengucapkan bunyi-bunyi bahasa dengan alat ucapnya dan bicara milik perseorangan (Ferliana, 2015: 5) Menurut Dhieni (2011: 3.4) perkembangan berbicara pada anak berawal dari anak menggumam maupun membeo. Dalam berbicara terkadang individu dapat menyesuaikan dengan keinginannya sendiri, berbicara bukanlah sekedar mengucapkan kata atau bunyi, tetapi merupakan suatu alat untuk mengekspresikan, menyatakan, menyampaikan, atau mengkomunikasikan pikiran, ide, maupaun perasaan. Berbicara merupakan suatu keterampilan berbahasa yang berkembang dan di pengaruhi oleh keterampilan menyimak, berbicara dan menyimak adalah kegiatan komunikasi dua arah atau tatap muka yang di lakukan secara langsung, kemampuan berbicara berkaitan dengan kosa kata yang di peroleh anak dari kegiatan menyimak dan membaca.

Freeman mendeskripsikan empat aktivitas motorik untuk menciptakan suara bicara yaitu sebagai berikut :

1. Respirasi yang menimbulkan energy untuk menghasilakan suara.

2. Fonasi merupakan produksi suara, ketika udara lewat diantara pita suara, pita suara tersebut bergetar dan menghasilkan suara.

3. Resonansi memberikan karakteristik khusus pada suara.

4. Artikulasi yaitu pergerakan mulut dan lidah yang membentuk suara sampai fonen (bunyi) yang membentuk ucapan atau bicara.

5. Mendengarkan, memahami dan memonitor bicara. (Ferliana dan Cht: 2015: 5.7)

Berdasarkan pendapat para ahli di atas, penulis menarik ke simpulan bahwa perkembangan bicara pada anak merupakan ekspresi oral dari bahasa, dimana terdapat bunyi-bunyi bahasa yang bermakna, dalam berbicara menggunakan 
artikulasi atau adanya kata-kata yang di gunakan untuk menyampaikan maksud. Bicara juga merupakan salah satu alat untuk mengekspresikan, menyatakan, menyampaikan, atau mengkomunikasikan pikiran, ide, maupun perasaan seseorang, sehingga bisa di mengerti dan di dengar orang lain, seseorang dapat berbicara dengan melalui proses belajar atau adanya proses peniruan.

b. Tujuan perkembangan berbicara

Nurbiana mendefinisikan bahwa tujuan berbicara adalah untuk memberitahukan, melaporkan, menghibur, membujuk, dan meyakinkan seseorang (Dhieni, 2011: 3.6). Pendapat lain di ungkapkan oleh Ferliana dan Cht (2015: 11.28) bahwa Salah satu bentuk komunikasi yang paling efektif adalah bicara, karena bagi anak bicara tidak sekedar merupakan ekspresi, karena bagi anak bicara tidak sekedar ekspresi melainkan juga berfungsi untuk mencapai tujuannya sebagai berikut :

(1) Pemuasan keinginan dan kebutuhan (2) Sarana untuk menarik perhatian orang lain (3) Sarana untuk membina hubungan social (4) Sarana untuk mengevaluasi diri sendiri, (5) Untuk dapat memengaruhi pikiran dan perasaan orang lain, (6) Untuk memengaruhi perilaku orang lain (7) Memberikan informasi, melatih anak bersosialisasi dan membantu pertumbuhan anak

Menumbuhkan rasa percaya diri anak (9) Mendidik, memotivasi, merangsang pemikiran dan memacu kreativitas (10) Meningkatkan hubungan sosial dan menentukan penilaian social (11) Meningkatkan prestasi akademik yang berhubungan dengan kemampuan berbicara (12) Membiasakan anak bersikap demokratis dalam menyampaikan atau menanggapi suatu pendapat serta melatih anak berpikir kritis.

c. Faktor-faktor perkembangan berbicara

Menurut Eileen ( 2010 : 21-31 ) perkembangan berbicara merupakan suatu proses yang kompleks, yang melibatkan beberapa faktor yag mempengaruhinya, yaitu :

1. Kecerdasan

2. Jenis kelamin

3. Kondisi fisik

4. Lingkungan keluarga

5. Kondisi ekonomi

6. Setting social atau lingkungan budaya

7. Bilingualism (2 bahasa)

d. Tipe perkembangan berbicara

Dhieni (2011: 3.6) mengatakan bahwa tipe perkembangan berbicara di bagi menjadi dua yaitu :

1. Egosentric Speech, terjadi ketika anak berusia $2-3$ tahun, dimana anak berbica kepada dirinya sendiri (monolog).

2. Socialized Speech, terjadi ketika anak berinteraksi dengan temannya ataupun lingkungannya. Terdapat 5 bentuk socialized speech yaitu: saling tukar informasi untuk tujuan bersama, penilaian terhadap ucapan atau tingkah laku orang lain, perintah, permintaan, ancaman, pertanyaan dan jawaban.

e. Tahapan perkembangan berbicara

Berikut ini merupakan tahapan perkembangan berbicara anak yang di kemukakan menurut beberapa para ahli yaitu : Hurlock mengemukakan dua kriteria untuk mengukur tingkat kemampuan berbicara anak, apakah anak berbicara secara benar atau hanya sekedar 'membeo' sebagai berikut:

1. Anak mengetahui arti kata yang digunakan dan mampu menghubungkannya dengan objek yang di wakilinya. 
2. Anak mampu melafalkan katakata yang dapat dipahami orang lain dengan mudah.

3. Anak memahami kata-kata tersebut bukan karena telah sering mendengar atau menduga-duga. (Dhieni: 2011: 3.6)

Menurut Vygotsky terdapat tiga penjelasan tahap perkembangan berbicara anak yang berhubungan erat dengan perkembangan berpikir anak yaitu:

1. Tahap Eksternal

Pada tahap ini terjadi ketika anak berbicara secara eksternal dimana sumber berpikir berasal dari luar diri anak. sumber berfikir ini sebagian besar berasal dari orang dewasa yang memberikan pengarahan, informasi, dan melakukan tanya jawab dengan anak.

2. Tahap Egosentris

Pada tahap ini dimana anak berbicara sesuai dengan jalan pikirannya dan pembicaraan orang dewasa bukan lagi menjadi persyaratan.

\section{Tahap Internal}

Pada tahap ini dimana dalam proses berfikir, anak telah memiliki penghayatan sepenuhnya. (Dhieni: 2011: 3.4-6.4)

Pendapat lain di ungkapkan oleh Eileen (2010: 141-152) bahwa tahap perkembangan berbicara anak berbeda pada usia 4 tahun dan 5 tahun sebagai berikut :

1. Perkembangan bicara anak usia 4 tahun

a. Menggunakan preposisi " di atas " di dalam " dan " di bawah ".

b. Menggunakan kata ganti kepunyaan secara konsisten "kepunyaannya" "kepunyaan mereka" "kepunyaan bayi".

c. Menjawab "kepunyaan siapa?" "siapa" "mengapa" "berapa jumlahnya".

d. Mengucapkan kalimat dengan struktur yang lebih kompleks "kucing itu berlari sebelum aku sempat melihat warnanya". e. Pengucapannya hampir seluruhnya bisa dipahami.

f. Mulai menggunakan kata kerja bentuk lampau dengan tepat "mama tadi menutup pintu" "papa pergi ke kantor tadi pagi".

g. Membicarakan kegiatan, kejadian dan orang yang tidak terjadi atau tidak ada di sekitarnya.

h. Mengubah intonasi suara dan struktur kalimat disesuaikan dengan pemahaman pendengarnya: kepada adik bayi "susunya habis" kepada ibunya "apakah adik bayi menghabiskan susunya?"

i. Mengucapkan nama depan dan belakang, jenis kelamin, nama saudara kandung, dan kadangkadang nomor telepon rumah.

j. Menjawab dengan tepat bila diberi pertanyaan apa yang dilakukan kalau dia lelah, kedinginan atau lapar.

k. Mengucapkan sajak dan menyanyikan lagu sederhana.

2. Perkembangan berbicara pada anak usia 5 tahun

a. Menguasai 1500 kosa kata atau lebih.

b. Menceritakan cerita yang sudah dia kenal ketika melihat gambar pada buku.

c. Menyebutkan kegunaan sesuatu: bola untuk dilambungkan, tempat tidur untuk tidur.

d. Mengenal dan menyebutkan empat sampai delapan warna.

e. Memahami lelucon sederhana, mengarang lelucon dan teka-teki.

f. Mengucapkan kalimat dengan lima sampai tujuh kata, bisa juga kalimat yang lebih panjang.

g. Menyebutkan nama kota di mana dia tinggal, tanggal ulang tahun dan nama orang tua. 
h. Menjawab telepon dengan tepat, memanggil orang yang ditelepon atau menerima pesan singkat.

i. Mengucapkan kalimat-kalimat yang hampir bisa dimengerti secara keseluruhan.

j. Menggunakan kata "bolehkah saya" dengan tepat.

Pendapat lain di ungkapkan oleh Aitchison berikut ini Tahap perkembangan bahasa dalam berbicara anak di antaranya :

Gunarti (2014:

mengungkapkan bahwa bercerita adalah suatu kegiatan yang dilakukan seseorang untuk menyampaikan suatu pesan, informasi atau sebuah dongeng belaka, yang bisa dilakukan secara lisan atau tertulis, cara penuturan cerita tersebut dapat dilakukan dengan menggunakan alat peraga atau tanpa alat peraga. Pendapat lain di ungkapkan oleh Dhieni (2011: 3.4-3.9,6.4) mengatakan bahwa bercerita adalah suatu kegiatan yang di lakukan seseorang secra lisan kepada orang lain dengan alat atau tanpa alat

Tabel 1. Tahap Perkembangan Bahasa (Harras And Bachari: 2009, hal 50

\begin{tabular}{|c|c|c|}
\hline $\begin{array}{c}\text { Tahap } \\
\text { perkembangan } \\
\text { bahasa }\end{array}$ & Usia & Keterangan \\
\hline Menangis & Lahir & $\begin{array}{l}\text { Tangisan ini bukan bagian dari perkembangan } \\
\text { bahasa tetapi sebagai komunikasi anak yang } \\
\text { bersifat instingtif seperti halnya system panggil } \\
\text { pada binatang. }\end{array}$ \\
\hline Mendengkur & $\begin{array}{c}6 \\
\text { minggu }\end{array}$ & $\begin{array}{l}\text { Dengan mendengkur bayi melatih peranti alat } \\
\text { ucapnya }\end{array}$ \\
\hline Meraban & 6 bulan & $\begin{array}{l}\text { Menghasilkan vocal dan konsonan secara serentak, } \\
\text { dan sebagai pelatihan bagi alat-alat ucap }\end{array}$ \\
\hline Pola intonasi & $\begin{array}{c}8 \\
\text { bulan }\end{array}$ & Anakmulai menirukan pola-pola intonasi \\
\hline Tutur satu kata & $\begin{array}{l}\text { Satu } \\
\text { tahun }\end{array}$ & Mulai mengucapkan tuturan satu kata \\
\hline Tutur dua kata & 18 bulan & $\begin{array}{l}\text { Kenaikan konsonan anak yang muncul secara } \\
\text { dramatis }\end{array}$ \\
\hline Infeksi kata & $\begin{array}{c}2 \\
\text { tahun }\end{array}$ & $\begin{array}{l}\text { Kata-kata yang di anggap remeh atau tidak penting } \\
\text { mulai digunakan }\end{array}$ \\
\hline $\begin{array}{l}\text { Kalimat Tanya } \\
\text { dan ingkar }\end{array}$ & $\begin{array}{c}21 / 4 \\
\text { tahun }\end{array}$ & $\begin{array}{l}\text { Anak mulai memperoleh kalimat Tanya dengan } \\
\text { kata Tanya seperti apa, siapa, bagaimana, kapan } \\
\text { dan sebagainya }\end{array}$ \\
\hline $\begin{array}{l}\text { Konstruksi yang } \\
\text { jarang dan } \\
\text { kompleks }\end{array}$ & $\begin{array}{l}5 \\
\text { tahun }\end{array}$ & $\begin{array}{l}\text { Anak sudah mulai memperoleh struktur kalimat } \\
\text { rumit }\end{array}$ \\
\hline $\begin{array}{l}\text { Tuturan yang } \\
\text { matang }\end{array}$ & 10 tahun & $\begin{array}{l}\text { Anak mampu menghasilkan kalimat perintah yang } \\
\text { setara dengan kalimat perintah orang dewasa. }\end{array}$ \\
\hline
\end{tabular}

\section{Hakikat metode bercerita}

a. Pengertian metode bercerita Berikut ini merupakan definisi metode bercerita yang diungkapkan menurut beberapa para ahli yaitu : tentang apa yang harus disampaikan dalam bentuk pesan, informasi atau hanya sebuah dongeng yang untuk didengarkan dengan rasa menyenangkan, oleh karena orang yang menyajikan cerita tersebut menyampaikannya dengan menarik. 
Selain itu bercerita merupakan suatu metode pengembangan bahasa yang dapat mengembangkan beberapa aspek fisik maupun psikologis bagi anak taman kanak-kanak sesuai tahap perkembangannya. Untuk kegiatan pendidikan di taman kanak-kanak bercerita adalah kegiatan yang dilakukan oleh guru kepada anak didik untuk menyampaikan materi pembelajaran dengan menarik. Selain itu metode bercerita adalah cara penyampaian atau penyajian materi pembelajaran secara lisan dalam bentuk cerita dari guru kepada anak didik taman kanak-kanak. Metode bercerita dilaksanakan dalam upaya memperkenalkan, memberikan keterangan, atau penjelasan tentang hal baru dalam rangka menyampaikan pembelajaran yang dapat mengembangkan berbagai kompetensi dasar anak taman kanak-kanak.

b. Bentuk-bentuk metode bercerita

Gunarti (2014: 5.5) mengungkapkan bahwa bentuk-bentuk metode bercerita terbagi dua jenis yaitu:

1) Bercerita tanpa alat peraga

Bercerita tanpa alat peraga dapat diartikan sebagai kegiatan bercerita yang dilakukan oleh guru atau orangtua tanpa menggunakan media atau alat peraga yang bisa di perlihatkan pada anak.

2) Bercerita dengan alat peraga Bercerita dengan menggunakan media atau alat pendukung untuk memperjelas penuturan cerita yang kita sampaikan. Alat peraga atau media tersebut di gunakan untuk menarik perhatian dan mempertahankan fokus perhatian anak dalam jangka waktu tertentu, alat peraga atau media yang di gunakan hendaknya aman bagi anak, menarik serta sesuai dengan tahap perkembangan anak. Bercerita dengan alat peraga dapat dibagi menjadi dua bentuk yaitu :

a. Bercerita dengan alat peraga langsung.
Bercerita dengan menggunakan alat peraga langsung yaitu kita bercerita dengan menggunakan alat peraga asli, sesuai dengan kenyataannya. alat peraga ini bisa berupa benda mati atau benda hidup, misalnya tas sekolah anak, botol minuman, pensil, baju, piring makan, sendok, garpu, kupu-kupu, kucing, ikan serta yang lainnya.

b. Bercerita dengan menggunakan alat peraga tidak langsung.

Bercerita dengan menggunakan alat peraga tidak langsung adalah bercerita dengan menggunakan alat peraga atau media bukan asli atau tiruan. Media arau alat peraga tersebut bisa terbuat dari kayu, pelastik atau dari bahan-bahan yang bisa kita buat sendiri, namun tentu saja tidak membahayakan. Bercerita dengan menggunakan alat peraga tak langsung ini terdiri atas bercerita dengan menggunakan gambar, buku cerita, papan flanel, dan boneka.

Pendapat snada diungkapkan oleh Dhieni (2011: 6.12) bahwa bentuk-bentuk metode cerita di bagi menjadi dua yaitu:

a) Bercerita tanpa alat peraga.

b) Bercerita dengan alat peraga.

Bercerita dengan alat peraga di bagi menjadi dua yaitu:

1. Bercerita dengan alat peraga langsung yaitu : guru bercerita dengan mempergunakan alat peraga langsung seperti tas, makhluk hidup yang nyata, binatang peliharaan atau tanaman.

2. Bercerita dengan alat peraga tak langsung atau benda tiruan, yaitu: bercerita dengan mempergunakaan alat peraga tiruaan, seperti binatang, hewan, yang di buat dari bahan kayu, plastik dan sebagainya. Kegiatan bercerita dengan alat peraga tak langsung terdiri dari: bercerita dengan gambar, bercerita dengan kartu, bercerita dengan papan flannel, bercerita dengan buku cerita, bercerita dengan boneka, bercerita sambil menggambar. 
c. Kelebihan dan kekurangan metode bercerita

Menurut Dhieni (2011: 6.9) dalam metode cerita memiliki kelebihan dan kekurangannya sebagai berikut:

1. Kelebihan antara lain:

a) Dapat menjangkau jumlah anak yang relatif lebih banyak.

b) Waktu yang tersedia dapat dimanfaatkan dwngan efektif dan efisien.

c) Pengaturan kelas menjadi lebih sederhana.

d) Guru dapat menguasai kelas dengan mudah.

e) Secara relatif tidak banyak memerlukan biaya.

2. Kekurangan antara lain:

a) Anak didik menjadi pasif, karena lebih banyak mendengarkan atau menerima penjelasan dari guru.

b)Kurang merangsang perkembangan kreativitas dan kemampuan siswa untuk mengutarakan pendapatnya.

c) Daya serap atau daya tangkap anak didik berbeda dan masih lemah sehingga sukar memahami tujuan pokok isi cerita.

d)Cepat menumbuhkan rasa bosan terutama apabila penyajiannya tidak menarik.

G. Hakikat bercerita dengan media papan flannel

Berikut ini akan di uraikan mengenai bercerita dengan media papan flannel dari definisi, cara pembuatan, cara melaksanakan kegiatan bercerita dan sebagainya yaitu :

a. Pengertian media papan flannel Kegiatan bercerita menggunakan papan yang terbuat dari bahan flannel dan potongan-potongan gambar lepas yang bisa di rekatkan dan potongan-potongan gambar lepas yang bisa direkatkan dan di lepaskan dari papan flannel. Potonfan gambar lepas tersebut menggambarkan tokoh cerita yang berupa potongan gambar manusia, binatang, tumbuhan dan sebagainya. Gambar-gambar tersebut bisa kita buat sendiri dari kain flanel atau menggunting gambar yang sudah ada, kemudian di rekatkan di kertas duplex dan di beri perekat untuk menempelkan gambar tersebut di papan flannel, papan flannel bisa kita buat sendiri dari kertas dupleks yang paling tebal atau sejenis kertas yang ketebalannya kira-kira $0,5 \mathrm{~cm}$. Kemudian dilapisi dengan kain flannel, apabila menginginkan papan flanel yang tahan lama, bisa kita buat dari papan tripleks kemudian di lapisi dengan karpet tipis. (Gunarti: 2014: 5.18-5.19) Bercerita dengan papan flannel merupakan kegiatan bercerita dengan menggunakan papan flannel dan potongan gambar lepas, potongan gambar lepas ini dapat di tempel pada papan flannel. (Dhieni: 2011: 6.436.45)

b. Ketentuan bercerita

Berikut ini merupakan beberapa ketentuan bercerita dengan papan flannel yang harus di perhatikan diantaranya sebagai berikut:

1. Pahami isi cerita dengan baik, kemudian rancanglah tokoh-tokoh cerita serta karakter pendukung yang di butuhkan.

2. Buatlah potongan gambar pada kertas duplex sesuai dengan tokoh cerita yang di butuhkan, kemudian lapisi dengan kain flannel yang tipis.

3. Ukuran gambar janganlah terlalu kecil.

4. Gambar di warnai atau di beri potongan kain flannel dengan warna yang menarik.

5. Buatlah naskah cerita untuk memudahkan kita dalam menuturkannya.

6. Simpan tokoh-tokoh cerita, karakter pendukung dan naskah cerita pada tempat yang aman sehingga memudahkan kita untuk menampilkannya kembali. (Gunarti: 2014: 5.18-5.19)

7. Beberapa pptongan gambar atau adegan di buat pada karton sesuai dengan isi cerita. 
8. Ada judul cerita, singkat dan sarat dengan nilai-nilai kehidupan, sosialisasi dan lingkungan anak.

9. Potongan gambar atau adegan di buat dan di bentuk sesuai dengan tokoh atau suasana cerita.

10. Ukuran gamabar relatif, paling kecil 10x15 cm.

11. Gambar di beri warna menarik dan tidak mengaburkan imajinasi anak.

12. Gambar dapat berupa bercerita 1 gambar tanpa suasana yang mendukung, dapat pula dilengkapi dengan suasana yang mendukung.

13. Gambar satu dan yang lainnya berkaitan dan menunjukkan satu kesatuan cerita.

14. Menggunakan gaya bahasa anak, isi cerita di buat dalam naskah.

(Dhieni: 2011: 6.43-6.45)

c. Langkah-langkah pelaksanaan

Berikut ini merupakan langkah-langkah pelaksanaan bercerita dengan menggunakan papan flannel sebagai berikut :

1)Dengan bimbingan guru anak mengatur posisi tempat duduknya.

2)Anak memperhatikan anda menyiapkan alat peraga yang diperlukan.

3)Anak memperhatikan anda yang menunjukkan alat peraga yang telah di siapkan, dan menyebutkan nama serta tokoh-tokoh dalam cerita.

4)Anak di beri kesempatan memberikan judul cerita.

5)Anak mendengarkan anda tentang judul cerita yang sebenarnya.

6)Anak memperhatikan anda yang mulai bercerita sambil menempelkan.

7)Potongan gambar secara bergantian pada papan flannel sesuai alur cerita.

8) Setelah selesai bercerita anda menempelkan potongan gambar seluruhnya.
9)Anak diberi kesempatan untuk menyimpulkan isi cerita.

10) Anda melengkapi kesimpulan isi cerita dari anak.

(Dhieni: 2011: 6.43-6.45)

11) Siapkan papan flannel, tokoh-tokoh cerita dan karakter pendukung.

12) Susunlah urutan penempelannya sesuai alur cerita.

13) Atur posisi anak yang memberikan kenyamanana bagi anak untuk menyimak cerita.

14) Menyebutkan judul cerita.

15) Mengenalkan tokoh-tokoh cerita.

16) Guru atau orang tua dapat mulai bercerita sambil menempelkan potongan-potongan gambar secara bergantian pada papan flannel sesuai dengan alur cerita.

17) Ketika cerita sudah selesai di tuturkan, kita dapat mengajukan pertanyaan seputar cerita tersebut, misalnya tentang judul cerita, tokoh cerita, isi cerita, bisa juga meminta pendapat atau komentar anak mengenai cerita tersebut. Dapat pula kita minta anak memperagakan karakter suatu tokoh atau suatu kejadian dalam cerita tersebut.

18) Bersama-sama dwngan anak menyimpulkan isi cerita tersebut, termasuk mencari pelajaran dari isi cerita juga mencari solusi terbaik dari permasalahan yang ada pada cerita tersebut.

19) Akhiri kegiatan bercerita dengan meminta anak untuk menceritakan kembali isi cerita atau tutup dengan nyanyian yang menggambarkan isi cerita tersebut. (Gunarti: 2014: 5.18-5.19)

20) Evaluasi

Setelah melakukan kegiatan cerita dengan menggunakan media papan flannel maka adanya evaluasi, sehingga mengetahui sejauh mana anak dapat menyimak kegiatan bercerita tersebut, adanya tanya jawab tentang isi cerita, tokoh dalam cerita, isi gambar, atau anak 
diminta bertanya tentang isi cerita yang telah di ceritakan. dan penting untuk dapat memberi kesempatan pada satu atau dua orang anak untuk menceritakan kembali cerita tersebut. (Dhieni: 2011: 6.43-6.45)

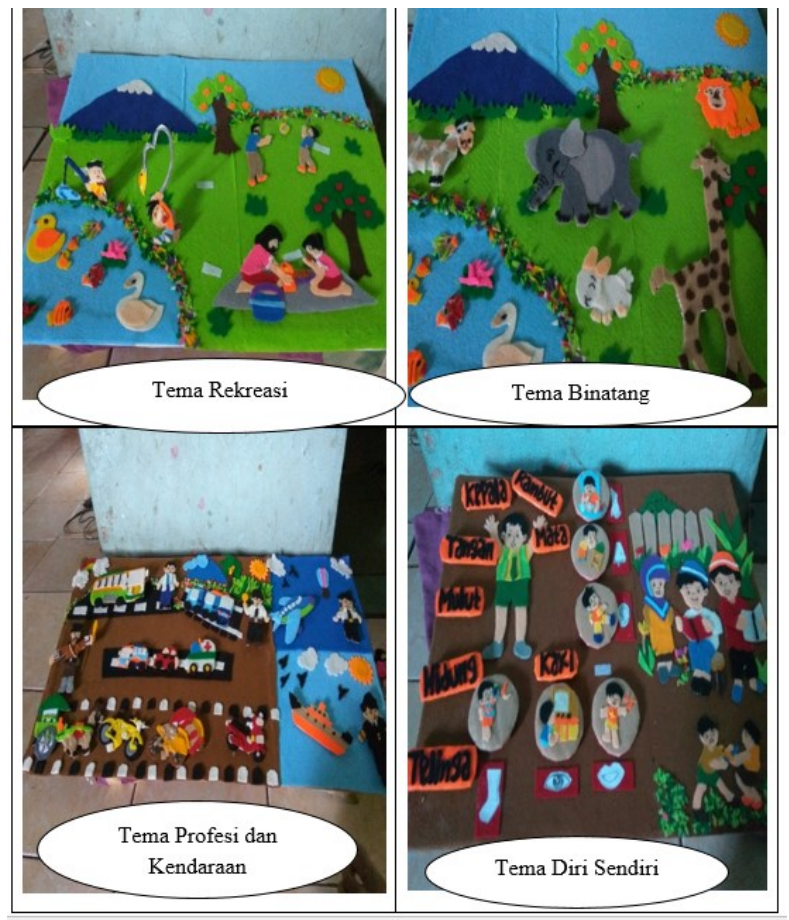

Gambar 1 Media Papan Flanel

\section{METODOLOGI PENELITIAN Desain Penelitian}

Hubungan antara komponen tersebut menunjukkan sebuah siklus atau kegiatan berulang-ulang, aktivitas dalam penelitian tindakan ini melalui siklus dan tahapan tertentu. Menurut Arikunto (2016, hlm. 144) aktivitas dalam penelitian tindakan ini melalui siklus dan tahapan tertentu, terlihat pada gambar berikut: Hubungan antara komponen tersebut menunjukkan sebuah siklus atau kegiatan berulang-ulang, aktivitas dalam penelitian tindakan ini melalui siklus dan tahapan tertentu. Menurut Arikunto (2016, hlm. 144) aktivitas dalam penelitian tindakan ini melalui siklus dan tahapan tertentu, terlihat pada gambar berikut:

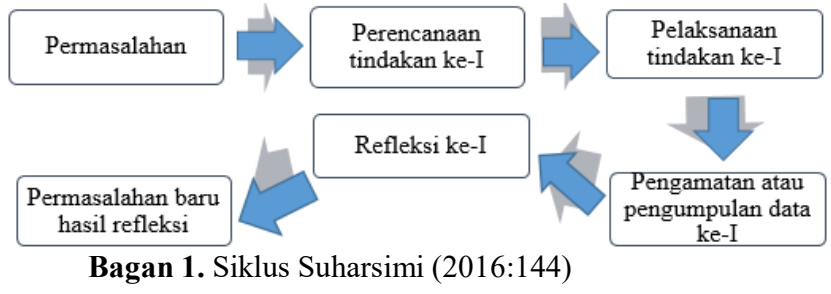

Tabel 2 Instrument penelitian berbicara anak usia 4-5 tahun

\begin{tabular}{|c|c|c|c|}
\hline Variabel & $\begin{array}{c}\text { Aspek } \\
\text { pengamatan }\end{array}$ & Indikator & $\begin{array}{r}\text { Nomo } \\
\text { butir }\end{array}$ \\
\hline \multirow[t]{9}{*}{$\begin{array}{l}\text { Kemampuan } \\
\text { berbicara }\end{array}$} & \multirow[t]{2}{*}{$\begin{array}{l}\text { Menerima } \\
\text { bahasa }\end{array}$} & Menyimak perkataan orang lain & 1 \\
\hline & & Memahami cerita yang di bacakan & 2 \\
\hline & \multirow{6}{*}{$\begin{array}{l}\text { Mengungkap } \\
\text { kan bahasa }\end{array}$} & Menjawab pertanyaan sederhan & 3 \\
\hline & & $\begin{array}{l}\text { Mengungkapkan perasaan dengan } \\
\text { kata sifat }\end{array}$ & 4 \\
\hline & & Menyebutkan kata-kata yang di kenal & 5 \\
\hline & & $\begin{array}{l}\text { Mengutarakan pendapatkepada orang } \\
\text { lain }\end{array}$ & 6 \\
\hline & & $\begin{array}{l}\text { Menyatakan alas an terhadap sesuatu } \\
\text { yang di inginkan atau ketidak } \\
\text { setujuan }\end{array}$ & 7 \\
\hline & & $\begin{array}{l}\text { Menceritakan kembali cerita yang } \\
\text { pernah di dengar }\end{array}$ & 8 \\
\hline & Keaksaraan & $\begin{array}{l}\text { Mengenal suara-suara hewan atau } \\
\text { benda yang ada di sekitarnya }\end{array}$ & 9 \\
\hline & & Jumlah & 9 \\
\hline
\end{tabular}

\section{HASIL PENELITIAN DAN PEMBAHASAN Pembahasan}

Setelah dilakukan berbagai kegiatan pada siklus I, siklus II dan siklus III, diperoleh hasil penelitian meningkatkan perkembangan berbicara anak usia 4-5 tahun melalui bercerita dengan menggunakan papan flannel berhasil meningkat dari sebelum tindakan $36 \%$, menjadi $49 \%$, meningkat $72 \%$, semakin meningkat menjadi $87 \%$ pada siklus III. Perkembangan berbicara anak berhasil meningkat karena adanya proses perbaikan kualitas pembelajaran, khususnya pada aspek perkembangan berbicara. Interaksi gurudan peserta didik juga di tingkatkan, peningkatan perkembangan berbicara anak sudah sesuai dengan kriteria keberhasilan tindakan yang telah di sepakati antara peneliti dan 2 kolaborator yaitu sebesar 75 $\%$. Meningkatkan perkembangan berbicara anak usia 4-5 tahun dari 
sebelum tindakan sampai siklus III dapat dilihat pada grafik berikut:
Berdasarkan data pada table dan grafik hasil analisis di atas terlihat kemampuan

Tabel 4 Hasil analisis data siklus I, siklus II dan siklus III

\begin{tabular}{|c|c|c|c|c|c|c|c|c|}
\hline \multirow[b]{2}{*}{ No } & \multirow[b]{2}{*}{ Responden } & \multicolumn{3}{|c|}{ Skor } & \multicolumn{3}{|c|}{ persentase } & \multirow{2}{*}{$\begin{array}{c}\text { Peningka } \\
\text { an }(\%)\end{array}$} \\
\hline & & Siklus I & $\begin{array}{c}\text { Siklus } \\
\text { II }\end{array}$ & Siklus III & Siklus I & Siklus II & Siklus III & \\
\hline 1 & Nabila & 17 & 27 & 27 & 56 & 90 & 90 & 56 \\
\hline 2 & Rizal & 12 & 19 & 27 & 40 & 63 & 90 & 13 \\
\hline 3 & Afdan & 15 & 26 & 27 & 50 & 86 & 90 & 46 \\
\hline 4 & Fahmi & 15 & 27 & 27 & 50 & 90 & 90 & 50 \\
\hline 5 & Fadli & 12 & 16 & 23 & 40 & 53 & 76 & 17 \\
\hline 6 & Keyla & 13 & 19 & 24 & 43 & 63 & 80 & 26 \\
\hline 7 & Yunus & 15 & 23 & 26 & 50 & 76 & 86 & 40 \\
\hline 8 & Zaki & 12 & 22 & 26 & 40 & 73 & 86 & 27 \\
\hline 9 & Ridho & 17 & 25 & 26 & 56 & 83 & 86 & 53 \\
\hline 10 & Rafka & 15 & 24 & 27 & 50 & 80 & 90 & 40 \\
\hline 11 & Rizwan & 14 & 24 & 26 & 46 & 80 & 86 & 40 \\
\hline 12 & Keysa & 18 & 27 & 27 & 60 & 90 & 90 & 60 \\
\hline 13 & Difa & 18 & 26 & 27 & 60 & 86 & 90 & 56 \\
\hline 14 & Faris & 13 & 21 & 26 & 43 & 70 & 86 & 27 \\
\hline 15 & dida & 18 & 27 & 27 & 60 & 90 & 90 & 60 \\
\hline & Jumlah & 224 & 353 & 393 & 744 & 1.093 & 1.306 & 611 \\
\hline & Rata-rata & 14 & 23 & 26 & 49 & 72 & 87 & 40 \\
\hline
\end{tabular}

Tabel 3 Hasil analisis data siklus I, siklus II dan siklus III

\section{Chart Title}

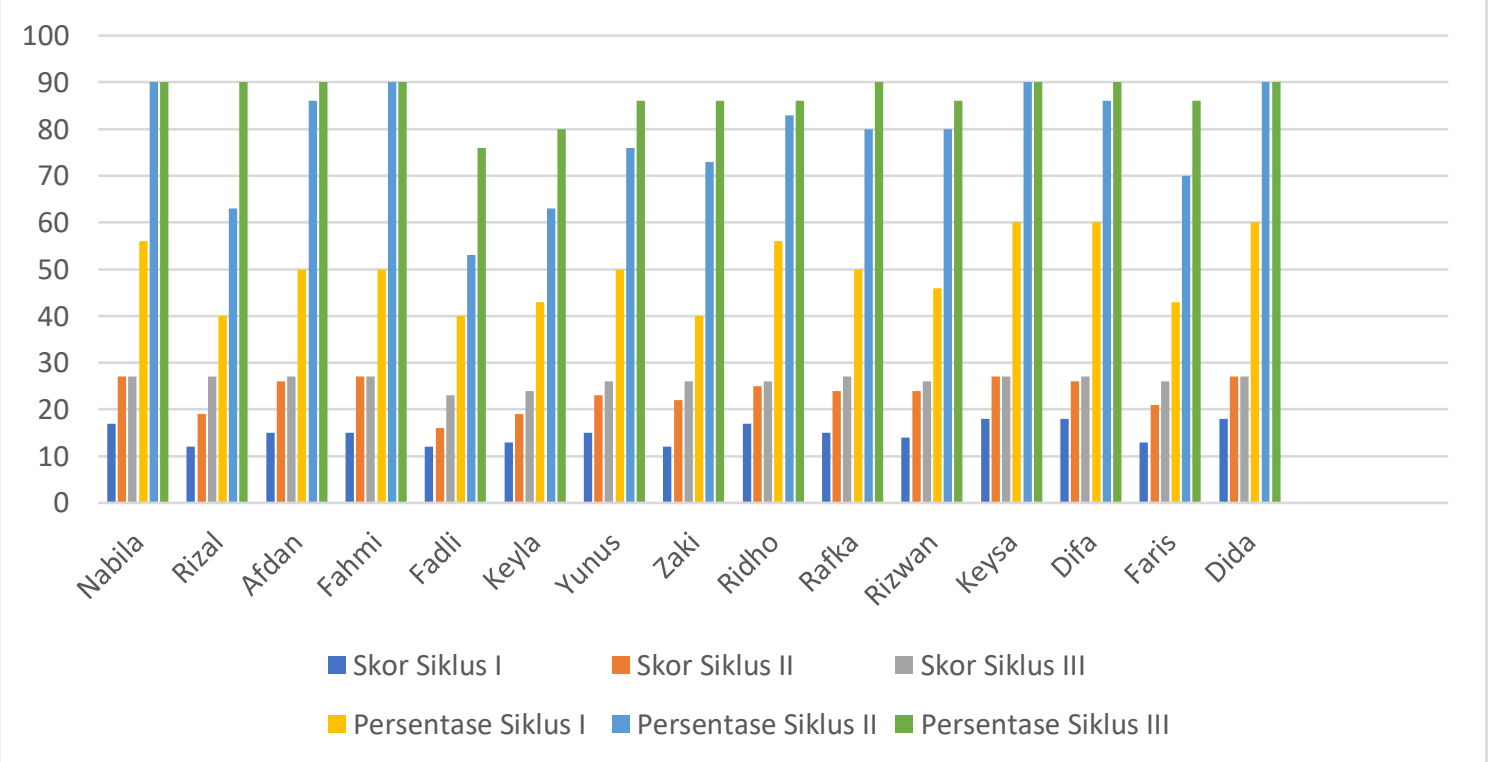

berbicara anak setelah diberi tindakan 
mengalami peningkatan yang cukup besar dari hasil observasi pra penelitian sampai ke siklus I peningkatan sebesar $13 \%$, sedangkan dari siklus I ke siklus II peningkatan sebesar $28 \%$, dan dari siklus II ke siklus III peningkatan sebesar $88 \%$.

\section{Interpretasi data}

Berdasarkan data yang telah disampaikan pada analisis data, hipotesis diterima apabila terdapat peningkatan persentase kemampuan berbicara anak setelah dilakukan tindakan pada siklus I dan siklus II, berikut table persentase kemampuan dari pra penelitian sampai siklus III:

\begin{tabular}{|c|c|c|c|c|}
\hline $\begin{array}{c}\text { Persentas } \\
\text { e } \\
\text { Pra } \\
\text { penelitian }\end{array}$ & $\begin{array}{l}\text { Persenta } \\
\text { se } \\
\text { Siklus } \\
\text { I }\end{array}$ & $\begin{array}{l}\text { Persenta } \\
\text { se } \\
\text { Siklus } \\
\text { II }\end{array}$ & $\begin{array}{l}\text { Perse } \\
\text { ntase } \\
\text { siklus } \\
\text { III }\end{array}$ & Keterangan \\
\hline $36 \%$ & $49 \%$ & $72 \%$ & $87 \%$ & $\begin{array}{l}\text { Persentase } \\
\text { perkembangan } \\
\text { berbicara pada } \\
\text { siklus III lebih } \\
\text { besar dari pada } \\
\text { persentase } \\
\text { perkembangan } \\
\text { pra penelitian, } \\
\text { siklus I, siklus II, } \\
\text { sehingga dapat } \\
\text { disimpulkan } \\
\text { bahwa kegiatan } \\
\text { pembelajaran } \\
\text { dengan melalui } \\
\text { bercerita dengan } \\
\text { papan flannel } \\
\text { dapat meningkatkan } \\
\text { perkembangan } \\
\text { berbicara anak } \\
\text { usia 4-5 tahun }\end{array}$ \\
\hline
\end{tabular}

Terjadinya peningkatan persentase perkembangan berbicara anak berdasarkan hasil analisis, peneliti menyimpulkan hal ini terjadi karena kegiatan pembelajaran meningkat, meningkatkan perkembangan berbicara dilakukan melalui bercerita dengan menggunakan media papan flannel. Selain di pengaruhi oleh media, keberhasilan meningkatkan perkembangan berbicara di pengaruhi oleh keterampilan guru dalam mengajar dan menstimulus anak untuk berbicara dan mengungkapkan pendapatnya.

Meningkatnya perkembangan berbicara anak tergantung banyaknya peluang yang disediakan tentang keterlibatan dalam penggunaan bahasa yang di sediakan oleh guru, untuk mengeksplorasi interaksi dan perkembangan berbicara anak, pertanyaan guru dalam menanggapi anak harus dilakukan dengan pertanyaan terbuka, karena dengan guru memberikan pertanyaan terbuka akan memberikan kesempatan yang luas kepada anak untuk meningkatkan perkembangan berbicara anak.

\section{KESIMPULAN}

Hasil penilaian dari prasiklus rata-rata $36 \%$, siklus I adanya peningkatan rata-rata sebesar 49\%, siklus II meningkat kembali sebesar $72 \%$, dan siklus III mencapai $87 \%$ melebihi tingkat penilaian yang di harapkan. Adanya peningkatan dalam perkembangan berbicara anak melalui bercerita dengan menggunakan media papan flannel, yang sesuai dengan harapan.

1. Pelaksanaan pembelajaran yang dilakukan di Ra. As-Syifa kurang mendepankan aspek-aspek perkembangan anak, hal ini menyebabkan rendahnya perkembangan berbicara anak, oleh karna itu penelitian dilakukan dengan metode bercerita yang menggunakan media papan flannel, sehingga dapat meningkatkan perkembangan berbicara anak. Karena anak akan lebih mudah terstimulus dan perkembangan berbicara anak akan terasah, maka anak akan lebih mudah untuk mengungkapkan perasaan dan pendapatnya, serta perkembangan berbicara anak akan lebih baik dalam berkomunikasih.

2. Melalui bercerita dengan menggunakan media papan flannel, perkembangan berbicara anak Ra AsSyifa, di kelas A telah menunjukan perkembangan yang cukup signifikan sesuai dengan harapan 


\section{DAFTAR PUSTAKA}

Arikunto, Suharsimi, Dkk. (2016). Penelitian Tindakan Kelas. Jakarta: Bumi Aksara

Chaer Abdul. (2015). Psikolinguistik Kajian Teoretik. Jakarta: Rineka Cipta

Depdiknas. (2009). Permendiknas No 58 Tahun 2009 Tentang Standar Pendidikan

Anak usia Dini. Jakarta. Depdiknas

Dhieni Nurbiana, Dkk. (2011). Metode Pengembangan Bahasa. Jakarta: Universitas Terbuka

Eileen, Allen. (2010). Profil Perkembangan Anak. Jakarta: Pt Indeks

Ferliana Jovita Maria Dan Cht Agustina, (2015). Meningkatkan Kemampuan Berkomunikasi Aktif Pada Anak usia Dini. Jakarta Timur: Pt. Luxima Metro Media

Gunarti Winda, Dkk. (2014). Metode Pengembangan Perilaku Dan Kemampuan Dasar Anak Usia Dini. Tangerang Selatan. Universitas Terbuka

Harras Kholid A dan Bachari Andika Dutha, (2009), Dasar-Dasar Psikolinguistik, Jakarta:

Universitas Pendidikan Indonesia Press

Satibi, Hidayat Otib. (2011). Metode Pengembangan Moral Dan Nilai Nilai Agama. Jakarta: Universitas Terbuka

Jun Kak. (2014). Jurus Jitu Mahir Mendongeng. Bantul Jogjakarta: Hikmah Media Utama

Masitoh, Dkk. (2012). Strategi Pembelajaran Tk. Tangerang Selatan: Universitas Terbuka

Mulyati Yeti, Dkk. (2014). Bahasa Indonesia. Tanggerang Selatan. Universitas: Terbuka

Moeslichatoen R. (2004). Metode Pengajaran Di Taman Kanak-Kanak. Jakarta: Rineka Cipta
Nugraha Ali, Dkk. (2008). Kurikulum Dan Bahan Belajar Tk. Jakarta: Universitas

Rini Hidayani, Dkk. (2011). Psikologi Perkembangan Anak. Jakarta: Universitas Terbuka

Soetjiningsih Christiana Hari. (2012). Perkembangan Anak. Jakarta: Prenada

Seefeldt Carol dan Wasik Barbara A. (2008). Pendidikan Anak Usia Dini. Jakarta: Pt Indeks 